\title{
Fertilitas Spermatozoa Babi Landrace dalam Pengencer Modifikasi Zorlesco dengan Susu Kacang Kedelai
}

\author{
J. A. Tamoes ${ }^{1,2}$, W. M. Nalley ${ }^{3}$ dan T. M. Hine ${ }^{3}$ \\ 1) Mahasiswa Pascasarjana Program Studi Ilmu Peternakan Universitas Nusa Cendana \\ ${ }^{2)}$ UPT Pembibitan Ternak dan Pengembangan Produksi Makanan Ternak Dinas Peternakan \\ Provinsi Nusa Tenggara Timur \\ 3) Fakultas Peternakan Universitas Nusa Cendana Kupang \\ E-mail: jonathantamoes@gmail.com
}

\begin{abstract}
ABSTRAK
Penelitian ini dilakukan untuk mengetahui efektifitas pengencer Zorlesco dan modifikasi Zorlesco dengan beberapa jenis susu kacang kedelai dalam mempertahankan fertilitas spermatozoa babi landrace yang disimpan pada suhu $18^{\circ} \mathrm{C}$. Semen dikoleksi dua kali seminggu menggunakan metode masase dari dua ekor pejantan landrace berumur $\pm 2,5$ tahun yang memiliki kodisi tubuh dan organ reproduksi yang sehat. Semen yang memenuhi syarat setelah di evaluasi secara makroskopis dan mikroskopis diencerkan dengan Zorlesco (P0) atau modifikasi Zorlesco dengan suplementasi susu kacang kedelai murni (P1), Metabolis (P2) dan Melilea (P3), dan masing-masing perlakuan diulang lima kali. Semen selanjutnya disimpan pada suhu $18^{\circ} \mathrm{C}$. Data tentang motilitas dan viabilitas spermatozoa di analisis dengan ANOVA dan dilanjutkan dengan uji Duncan. Hasil analisis statistik menunjukkan bahwa modifikasi pengencer Zorlesco yang ditambahkan dengan susu kedelai 5\% tidak dapat $(\mathrm{P}<0.05)$ mempertahankan motilitas dan viabilitas spermatozoa lebih tinggi dari pengencer Zorlesco selama 42 jam penyimpanan.
\end{abstract}

Kata Kunci: susu kacang kedelai, modifikasi Zorlesco, motilitas Spermatozoa, viabilitas spermatozoa, babi landrace

\section{Sperm Fertility of Landrace Boar in Modified Zorlesco Extender with Soymilk}

\begin{abstract}
A research has been done to study the effectiveness of Zorlesco extender and modified Zorlesco extender with soymilk to maintain sperm fertility of landrace boar preserved at $18^{\circ} \mathrm{C}$. Semen was collected twice a week by hand massage from 2 heads of \pm 2.5 years old landrace boar. A Completely Randomized Design with 4 treatments and 5 replications was used to organized the experiment. The fresh evaluated semen were extended with zorlesco $P(0)$, zorlesco + hand made soymilk $P(1)$, zorlesco + Metabolis ${ }^{T M}$ soymilk $P(2)$, and zorlesco + Melilea ${ }^{T M}$ soymilk $P(3)$. Extended semen were preserved at $18^{0} \mathrm{C}$. Analysis of variance and Duncan test were used to analyzed data of motility and viability of sperm. The result showed that the modification of diluent Zorlesco added with 5\% soymilk could not defend by sperm motility and viability spermatozoa compared with Zorlesco for 42 hours storage $(P<0.05)$.
\end{abstract}

Keyword: Soymilk, modified zorlesco, sperm motility, sperm viability, landrace boar

\section{PENDAHULUAN}

Usaha peternakan babi di Nusa Tenggara Timur (NTT) masih merupakan peternakan rakyat berskala kecil atau skala rumah tangga, dimana upaya peningkatan mutu genetiknya masih kurang mendapat perhatian. Salah satu upaya yang dilakukan untuk meningkatkan mutu genetik ternak babi adalah menerapkan program inseminasi buatan (IB). 
Melalui teknologi ini dimungkinkan terjadinya perkawinan antara pejantan unggul yang terdapat di suatu daerah/wilayah dengan betina yang ada di daerah/wilayah lain (Toelihere,1993; Ardana dan Putra, 2008).

Pencapaian tujuan program IB tergantung pada beberapa faktor yaitu kualitas semen, ketrampilan inseminator, cara mempertahankan kualitas semen segar setelah ejakulasi maupun selama preservasi semen. Semen segar tidak bertahan lama dalam penyimpanan in vitro, bahkan hanya bertahan \pm 3-4 jam (Blakely dan Bade, 1992). Oleh karena itu perlu dilakukan upaya preservasi agar kualitas semen tetap dipertahankan dalam kurun waktu yang relatif lama. (Toelihere, 1993 dan Beaulieu et al., 2005).

Pengencer Zorlesco mengandung karbohidrat (glukosa) sebagai sumber energi, memiliki sifat penyangga dengan toksisitas yang rendah, dan mengandung sistein sehingga memberikan sumber nutrisi bagi spermatozoa selama penyimpanan dan melindungi spermatozoa dari pengaruh cold shock (Johnson et al., 2000; Gadea, 2003; Sumardani, 2007).

Susu kacang kedelai dapat digunakan sebagai salah satu komponen bahan pengencer semen babi karena kandungan DHAnya mencapai 0,30-0,60\%. Selain itu susu kedelai juga mengandung karbohidrat, protein, lipoprotein dan lesithin yang berfungsi dalam mempertahankan dan melindungi integritas membran plasma spermatozoa (Aboagla et al., 2004; Bergeron dan Manjunath, 2006).

Menurut Campbell et al. (2002) jika lesitin atau fosfolipid ditambahkan ke dalam air, maka molekulnya mengumpul dan membentuk agregat untuk melindungi bagian hidrofobiknya, sehingga dapat mempertahankan dan melindungi integritas selubung lipoprotein pada spermatozoa dari cekaman dingin selama proses pengolahan semen cair.

Berdasarkan latar belakang tersebut maka dilakukan penelitian ini dengan tujuan untuk mengetahui efektifitas pengencer Zorlesco dan modifikasi Zorlesco dengan beberapa jenis susu kacang kedelai dalam mempertahankan fertilitas spermatozoa babi landrace yang disimpan pada suhu $18^{\circ} \mathrm{C}$.

\section{MATERI DAN METODE}

\section{Lokasi dan Waktu Penelitian}

Penelitian dilakukan pada bulan Februari sampai April 2013 di laboratorium Yayasan Williams dan Laura, desa Oelnasi, Kecamatan Kupang Tengah, Kabupaten Kupang sebagai tempat evaluasi semen dan UPT pembibitan Ternak Babi Dinas Peternakan Provinsi NTT sebagai tempat inseminasi.

\section{Materi Penelitian}

Ternak yang digunakan sebagai sumber semen adalah dua ekor babi pejantan landrace yang berumur $\pm 2,5$ tahun, yang berada dalam kondisi sehat, mempunyai organ reproduksi normal dan telah terlatih untuk ditampung semennya.

Peralatan yang digunakan: a) satu set alat penampungan; b) satu set alat pembuatan pengencer semen; c) satu set alat evaluasi semen; d) satu set alat Inseminasi pada ternak babi.

Bahan penelitian yang digunakan adalah Zorlesco (Tabel 1) yang dimodifikasi dengan penambahan bubuk susu kedelai murni, susu kedelai metabolis ${ }^{\circledR}$, susu kedelai melilea ${ }^{\circledR}$. Pengencer Zorlesco sebagai bahan pengencer dasar disiapkan sesuai dengan petunjuk Johnson et al. (2000), dengan komposisi terdiri dari Glukosa, EDTA (Ethylene diamine tetraacetic Acid), Sodium sitrat, Sodium bikarbonat, Tris aminomethan, Asam sitrat dan Sistein (Tabel 1).

Tabel 1. Komposisi bahan dasar pengencer M-Zorlesco

\begin{tabular}{lr}
\hline \hline Bahan Kimia (g/100ml) & Jumlah \\
\hline Glukosa (g) & 1,15 \\
EDTA (g) & 0,23 \\
Sodium-sitrat & 1,17 \\
Sodium-bikarbonat (g) & 0,125 \\
Tris Aminomethan (g) & 0,65 \\
Asam-sitrat (g) & 0,41 \\
Sistein (g) & 0,01 \\
Penisilin (IU) & 100.000 \\
Streptomisin (mg) & 100 \\
\hline Ket: EDTA (Ethylenediamine-tetra-acetic & acid), M- \\
Zorlesco (Modifikasi Zorlesco) &
\end{tabular}


Tabel 2. Komposisi bahan pengencer semen babi

\begin{tabular}{lcccc}
\hline \hline Bahan Pengencer & \multicolumn{4}{c}{ Perlakuan (\%) } \\
\cline { 2 - 5 } & P0 & P1 & P2 & P3 \\
\hline Zorlesco & 100 & 95 & 95 & 95 \\
KK Murni & - & 5 & - & - \\
Metabolis ${ }^{\circledR}$ & - & - & 5 & - \\
Melilea & - & - & - & 5 \\
\hline Total & 100 & 100 & 100 & 100 \\
\hline Kol
\end{tabular}

Ket : KK ( Kacang Kedelai)

Modifikasi bahan pengencer Zorlesco yang ditambahkan dengan 5\% susu kacang kedelai murni (P1), 5\% susu kacang kedelai metabolis ${ }^{\circledR}(\mathrm{P} 2)$, dan $5 \%$ susu kacang kedelai melilea ${ }^{\circledR}(\mathrm{P} 3)$ tertera dalam Tabel 2.

Penampungan semen dengan metode masase pada bagian corpus penis (Ardana dan Putra, 2008). Semen di evaluasi secara makroskopis dan mikroskopis. Semen segar yang memenuhi syarat yaitu memiliki konsentrasi spermatozoa $\geq 200 \times 10^{6} \mathrm{sel} / \mathrm{mL}$, persentase motilitas $\geq 60 \%$, persentase hidup spermatozoa $\geq 70 \%$ dan abnormalitas $\leq 20 \%$.

Rancangan yang digunakan adalah rancangan acak lengkap (RAL) yang terdiri dari empat perlakuan dan lima kali ulangan. Parameter dalam penelitian ini adalah: karakteristik semen segar, motilitas dan viabilitas spermatozoa babi landrace secara in vitro.

Pengamatan dilakukan setiap enam jam. Data dianalisis dengan sidik ragam dan jika terdapat perbedaan nyata dilanjutkan uji Duncan, dengan program software SPSS 17.0 for windows.

\section{HASIL DAN PEMBAHASAN}

\section{Karakteristik Semen Segar Babi Landrace}

Hasil pengamatan secara makroskopis menunjukkan bahwa volume semen yang diperoleh sebanyak $212 \pm 10,95 \mathrm{~mL}$, konsistensi encer dengan $\mathrm{pH} 6,64 \pm 0,25$ (Tabel 3).

Rataan volume semen yang diperoleh hampir sama dengan hasil penelitian Ax et al. (2000a), Robert (2006) dan Sumardani (2007) yaitu 200-250 mL. Warna semen hasil penelitian adalah putih susu dengan konsistensi encer dengan $\mathrm{pH}$ fisiologis yaitu 6,4-7,0 dan memiliki kisaran $\mathrm{pH}$ sama dengan hasil penelitian Garner dan Hafez (2000) yaitu 6,47,8 . Hasil penelitian terhadap $\mathrm{pH}$ semen masih lebih rendah dari penelitian Sumardani (2007) yaitu 7,78 $\pm 0,44$ dan Gadea (2003) yaitu $7,4 \pm 0,2$. Faktor-faktor tersebut terjadi karena yang mempengaruhi adalah umur, tingkat rangsangan, frekuensi ejakulasi, lingkungan dan kualitas pakan (Johnson et al., 2000 dan Feradis, 2010).

Rataan motilitas spermatozoa yang diperoleh pada penelitian ini yaitu $78,00 \pm 2,74 \%$ dan masih berada pada kisaran persentase motilitas spermatozoa hasil penelitian Garner dan Hafez (2000) yaitu 50$80 \%$. Faktor-faktor yang mempengaruhi motilitas spermatozoa adalah bangsa, individu, umur ternak, jumlah ejakulat dan perubahan temperatur (Everett dan Bean, 1982; Shukla et al., 1992 dan Johnson et al., 2000).

Konsentrasi spermatozoa hasil penelitian mencapai $238 \pm 4,49 \times 10^{6} / \mathrm{ml}$ dan berada pada kisaran konsentrasi spermatozoa hasil penelitian Garner dan Hafez (2000) dan Robert (2006) yaitu $200-300 \times 10^{6} \mathrm{sel} / \mathrm{mL}$. Persentase abnormal spermatozoa hasil penelitian tergolong rendah yaitu $6,36 \pm 3,67 \%$ dan berada jauh dibawah standar maksimal abnormalitas yang dianjurkan yaitu 20\% (Garner dan Hafez 2000 serta Johnson et al., 2000).

\section{Fertilitas Spermatozoa Babi Landrace In Vitro}

\section{Motilitas spermatozoa}

Hasil analisis statistik menunjukkan bahwa penambahan susu kacang kedelai ke 
Tabel 3. Karakteristik semen segar babi landrace

\begin{tabular}{lc}
\hline \hline Parameter & Rataan \\
\hline Volume semen $(\mathrm{ml})$ & $212 \pm 10,95$ \\
Warna semen & Putih Susu \\
Konsistensi semen & Encer \\
pH semen & $6,64 \pm 0,25$ \\
Konsentrasi spermatozoa $\left(10^{6} \mathrm{sel} / \mathrm{ml}\right)$ & $238 \pm 4,49$ \\
Motilitas $(\%)$ & $78,00 \pm 2,74$ \\
Viabilitas $(\%)$ & $87,28 \pm 1,71$ \\
Abnormalitas $(\%)$ & $6,36 \pm 3,67$ \\
\hline
\end{tabular}

dalam pengencer Zorlesco tidak berpengaruh terhadap motilitas spermatozoa babi selama penyimpanan pada pengamatan jam ke-36 (Tabel 4). Berdasarkan nilai motilitas spermatozoa minimal untuk inseminasi buatan maka spermatozoa babi landrace dalam pengencer $\mathrm{P} 0, \mathrm{P} 3$ dan $\mathrm{P} 1$ masih bertahan hingga jam ke-42 pada suhu penyimpanan $18^{\circ} \mathrm{C}$, selanjutnya Perlakuan $\mathrm{P} 2$ hanya bertahan sampai pengamatan jam ke-36 (Tabel 4).

Beberapa penelitian menggunakan pengencer Zoelesco ${ }^{\circledR}$ memberikan informasi yang cukup baik, namun informasi tentang penggunaan pengencer Zoelesco ${ }^{\circledR}$ dan modifikasinya masih sangat kurang. Hasil penelitian ini lebih rendah jika dibandingkan dengan laporan Jhonson et al. (2000) dimana dengan penambahan 5\% Bovine Serum Albumin (BSA) dalam pengencer Zorlesco ${ }^{\circledR}$ mampu mempertahankan hingga hari ke sembilan dengan motilitas spermatozoa sebesar $50 \%$. Namun hasil penelitian ini lebih lama waktu preservasinya dibandingkan dengan laporan Sumardani (2007) yang menggunakan pengencer modifikasi Zorlesco dengan fruktosa pada semen cair babi Yorkshire yaitu hanya 36 jam.

Zhang et al. (2009) dalam penelitiannya menggunakan suplementasi $6 \%(\mathrm{w} / \mathrm{v})$ lesitin kedelai dalam pengencer BTS $^{\circledR}$ pada spermatozoa babi duroc mampu mempertahankan persentase motilitas sebesar $44 \%$ selama 48 jam penyimpanan. Fenomena ini terjadi karena adanya efek negatif akibat kandungan kalsium yang tinggi terdapat dalam larutan susu kedelai sehingga mempengaruhi kapasitasi spermatozoa. Kandungan kalsium pada perlakuan P2 cukup tinggi yaitu sebesar
$38,14 \%$, dibandingkan dengan perlakuan P1 yaitu $22,70 \%$ dan lebih rendah pada P3 yaitu $8,00 \%$. Tingginya kandungan kalsium dalam media pengencer akan memacu proses kapasitasi dini yang berlanjut dengan adanya fusi antara membran luar akrosom yang ditandai dengan peningkatan konsentrasi ion kalsium pada daerah equator membran kepala spermatozoa disebut reaksi akrosom sehingga spermatozoa menjadi labil dengan terlepasnya enzim-enzim seperti akrosin, hyaluronidase dan hidrolitik lainnya, yang terdapat pada akrosom dan bergabung ke dalam plasma semen, sehingga salah satu faktor terjadinya penurunan motilitas spermatozoa dengan cepat selama preservasi secara in vitro (Martinez et al., 1993; Feradis, 2010; Susilawati, 2011).

Penambahan suatu bahan kimia dengan konsentrasi yang tinggi akan meningkatkan tekanan osmotik sehingga dapat mempengaruhi keseimbangan elektrolit di dalam media pengencer tersebut. Perubahan tersebut menyebabkan air dari dalam sel keluar dengan cepat untuk mengencerkan bahan terlarut (solute) yang terdapat dalam konsentrasi yang tinggi di luar sel, akibatnya sel mengalami pengkerutan dan sel tersebut akan mati dan tidak bergerak (Martinez et al., 1993; Watson, 1996; Ax et al., 2000a).

Menurut Aalbers et al. (1985) konsentrasi kalsium ekstraseluler yang tinggi di dalam medium dapat menurunkan motilitas dan metabolisme spermatozoa dengan cepat karena adanya peningkatan kadar ion-ion intraseluler di dalam sel, sebaliknya rendahnya ion-ion intraseluler dalam media pengencer mampu menstimulir metabolisme sel. Hal yang sama dikemukakan oleh Hammerstedt et al. (1993) 


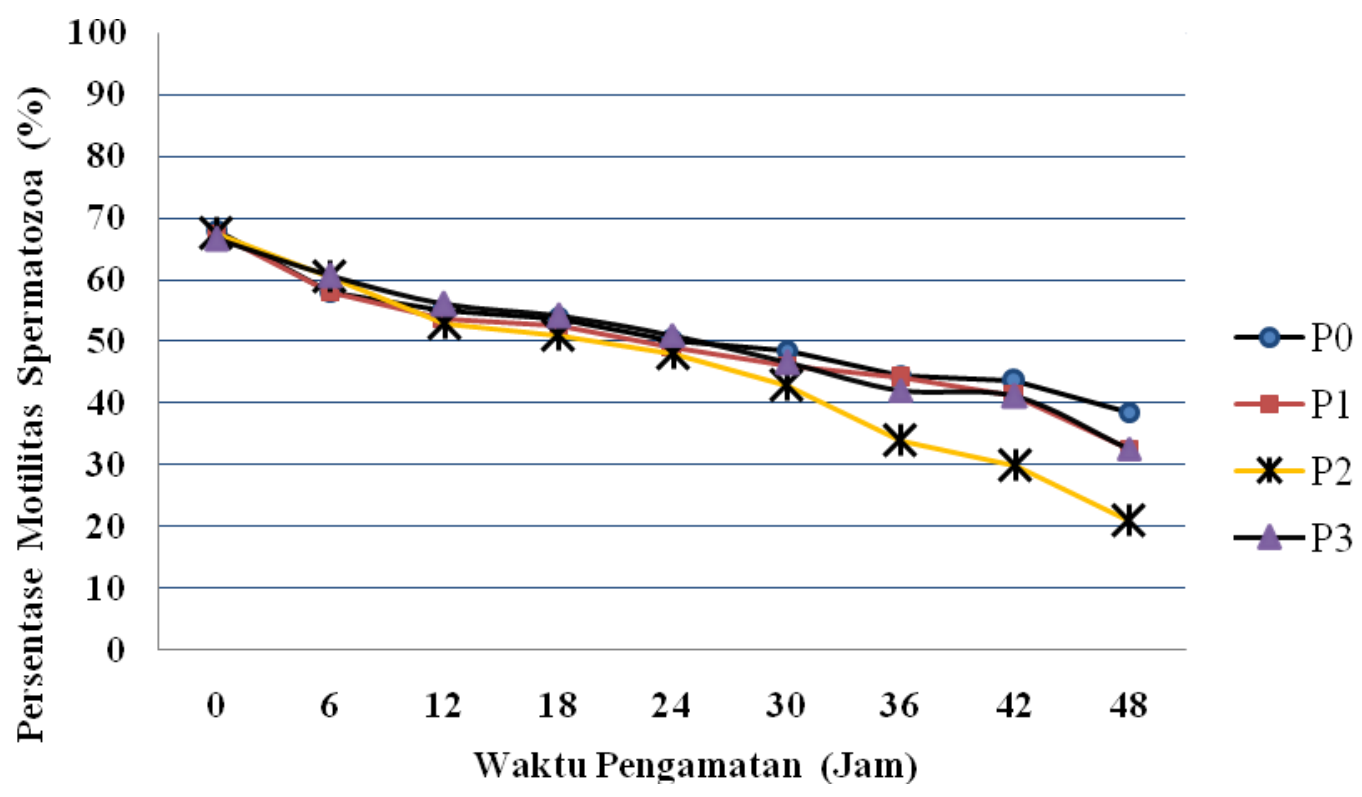

Gambar 1. Penurunan persentase motilitas spermatozoa babi landrace

bahwa kalsium sering dikaitkan dengan tingkat kapasitasi dan hiperaktif pada sel spermatozoa yang normal sehingga penurunan motilitas mudah terjadi sehingga ditandai spermatozoa tidak bergerak maupun bergerak ditempat.

Konsentrasi kalsium yang tinggi juga mempengaruhi sensitifitas spermatozoa terhadap kejutan dingin karena menyebabkan kerusakan membran sel secara langsung pada struktur dan fungsi seluler, misalnya penurunan proses metabolisme spermatozoa. Pengaruh utama dari kejutan dingin terhadap sel spermatozoa ialah penurunan motilitas dan daya hidup, perubahan permeabilitas dan perubahan komponen lipid pada membran. Jumlah spermatozoa motil mengalami penurunan disertai pelepasan enzim, perpindahan ion kalsium melewati membran sel, dan penurunan kandungan lipid seperti fosfolipid dan kolesterol yang sangat berperan dalam mempertahankan integritas struktur membran plasma, serta penurunan kemampuan sel spermatozoa akibat aliran kalsium (Weitze dan Petzoldt 1992; White 1993; Bailey dan Buhr 1994). Hal ini akan memacu proses kapasitasi yang berlanjut dengan adanya fusi antara membran luar akrosom dan ditandai dengan peningkatan konsentrasi ion kalsium pada daerah equator membran kepala spermatozoa disebut reaksi akrosom sehingga spermatozoa menjadi labil dengan terlepasnya enzim-enzim hidrolitik yang ada di akrosom (Feradis, 2010; Susilawati, 2011).

Pengencer Zorlesco ${ }^{\circledR}$ adalah bahan pengencer yang baik dan komplit untuk digunakan dalam mempertahankan motilitas spermatozoa babi selama preservasi pada suhu penyimpanan $15-20^{\circ} \mathrm{C}$ karena pengencer Zorlesco ${ }^{\circledR}$ memiliki sumber energi utama yaitu glukosa, zat penyangga (sodium sitrat, sodium bikarbonat, tris dan asam sitrat) yang mempertahankan tekanan osmotik dan keseimbangan elektrolit yang sesuai, sistein sebagai sumber protein dan antibiotik (penisilin dan streptomisin) serta tidak toksik terhadap spermatozoa (Johnson et. al., 2000; Sumardani, 2007).

Secara umum di antara perlakuan terjadi pola penurunan motilitas spermatozoa yaitu rataan berkisar antara $3,69-5,81 \%$ dalam pengencer Zorlesco dan modifikasi Zorlesco. Seiring waktu penyimpanan dengan bertambahnya umur spermatozoa dengan rataan pola penurunan motilitas pada pengamatan jam ke-0 hingga jam ke-12, penurunan cukup tinggi yaitu terlihat pada perlakuan P2 (7,25\%); 
Tabel 4. Rataan persentase motilitas spermatozoa semen cair babi landrace pada suhu penyimpanan $18^{\circ} \mathrm{C}$

\begin{tabular}{|c|c|c|c|c|}
\hline \multirow{2}{*}{$\begin{array}{l}\text { Pengamatan } \\
\text { Jam ke- }\end{array}$} & \multicolumn{4}{|c|}{ Perlakuan } \\
\hline & $\mathrm{P} 0$ & $\mathrm{P} 1$ & $\mathrm{P} 2$ & $\mathrm{P} 3$ \\
\hline 0 & $68,00 \pm 4,47^{\mathrm{a}}$ & $67,50 \pm 4,33^{a}$ & $67,50 \pm 5,59^{a}$ & $66,50 \pm 4,87^{\mathrm{a}}$ \\
\hline 6 & $58,00 \pm 10,37^{\mathrm{a}}$ & $58,00 \pm 10,81^{a}$ & $60,50 \pm 7,16^{\mathrm{a}}$ & $60,50 \pm 6,70^{a}$ \\
\hline 12 & $55,00 \pm 10,00^{\mathrm{a}}$ & $53,50 \pm 9,29^{a}$ & $53,00 \pm 9,09^{\mathrm{a}}$ & $56,00 \pm 6,52^{a}$ \\
\hline 18 & $53,50 \pm 8,94^{\mathrm{a}}$ & $52,50 \pm 8,29^{a}$ & $51,00 \pm 7,42^{a}$ & $54,00 \pm 7,41^{a}$ \\
\hline 24 & $50,00 \pm 7,07^{\mathrm{a}}$ & $49,00 \pm 7,42^{a}$ & $48,00 \pm 5,70^{a}$ & $51,00 \pm 7,42^{a}$ \\
\hline 30 & $48,50 \pm 7,42^{\mathrm{a}}$ & $46,00 \pm 5,48^{a}$ & $43,00 \pm 7,58^{\mathrm{a}}$ & $46,50 \pm 5,48^{a}$ \\
\hline 36 & $44,50 \pm 5,12^{a}$ & $44,00 \pm 4,18^{a}$ & $34,00 \pm 19,50^{\mathrm{a}}$ & $42,00 \pm 4,47^{\mathrm{a}}$ \\
\hline 42 & $43,50 \pm 4,18^{a}$ & $41,00 \pm 4,18^{a b}$ & $30,00 \pm 17,32^{b}$ & $41,00 \pm 2,24^{a b}$ \\
\hline 48 & $38,50 \pm 3,35^{a}$ & $32,50 \pm 18,20^{a}$ & $21,00 \pm 19,49^{\mathrm{a}}$ & $32,50 \pm 14,53^{a}$ \\
\hline
\end{tabular}

Keterangan: Angka diikuti dengan huruf yang berbeda pada baris yang sama menunjukkan perbedaan nyata $(\mathrm{P}<0,05)$

diikuti dengan P1 (7,00\%); P0 (6,50\%) dan P3 $(5,25 \%)$.

Pola penurunan motilitas spermatozoa pada pengamatan jam ke-12 hingga jam ke-30 teramati mulai rendah dan stabil dengan rataan berkisar antara 2,38-4,38\% (Gambar 1) hal ini diduga terjadi karena spermatozoa telah menyesuaikan dengan lingkungan eksternal. Hasil penelitian ini sependapat Chun-Xia et al. (2000); Johnson et al. (2000) dan Sumardani (2007) menyatakan bahwa salah satu faktor yang menentukan motilitas spermatozoa selama penyimpanan secara in vitro adalah penyesuaian bahan pengencer dan pengaruh cekaman dingin.

Pengamatan pada jam ke-30 hingga jam ke-42 terlihat pola penurunan motilitas mulai cepat terjadi pada perlakuan P1, P2 dan P3 yaitu berkisar antara 5,50-9.00\% dibandingkan dengan perlakuan P0 hanya sebesar $3,83 \%$. Penurunan persentase motilitas spermatozoa dimungkinkan karena terjadinya peroksidasi lipid sehingga rusaknya membran spermatozoa. Keadaan ini terjadi karena membran spermatozoa banyak mengandung asam lemak tak jenuh yang sangat rentan terhadap kerusakan peroksidasi (Maxwell dan Watson, 1996). Selanjutnya White (1993), Sikka (2004) dan Maldjian et al. (2005) menyatakan bahwa spermatozoa mamalia kaya akan asam lemak tidak jenuh dan sangat mudah terkena Reactive Oxygen Species (ROS) yang dapat mengakibatkan penurunan motilitas spermatozoa serta meningkatkan kerusakan morfologi yang berpengaruh terhadap kapasitasi spermatozoa dan reaksi akrosom sehingga menyebabkan fungsi membran selnya menurun akibat fosfolipid pada membran sel direduksi, sehingga sel mengalami kerusakan permanen.

Peroksidasi lemak pada membran plasma merupakan mekanisme kunci dari ROS yang mengakibatkan kerusakan spermatozoa dan infertilitas. Penurunan motilitas spermatozoa selama penyimpanan juga mungkin disebabkan oleh semakin berkurangnya zat-zat makanan di dalam pengencer, disamping itu spermatozoa mengalami cekaman dingin dan terjadinya perubahan $\mathrm{pH}$ akibat terbentuknya asam laktat di dalam pengencer.

\section{Viabilitas spermatozoa}

Analisis statistik menunjukkan bahwa penambahan susu kacang kedelai ke dalam pengencer Zorlesco tidak dapat mempertahankan persentase viabilitas spermatozoa babi landrace hingga jam ke-36 penyimpanan. Bahkan sebaliknya pada jam ke42 penyimpanan, viabilitas spermatozoa pengencer pada perlakuan P2 menurun secara drastis $\quad(\mathrm{P}<0,05) \quad$ dibandingkan dengan perlakuan lainnya (Tabel 4).

Viabilitas spermatozoa dalam hasil lebih rendah dari hasil penelitian Zhang et al. (2009) menggunakan modifikasi BTS dan suplemen 
Tabel 5. Rataan persentase viabilitas spermatozoa semen cair babi landrace pada suhu penyimpanan $18^{\circ} \mathrm{C}$

\begin{tabular}{ccccc}
\hline \hline Pengamatan & \multicolumn{4}{c}{ Perlakuan } \\
\cline { 2 - 5 } Jam Ke- & $\mathrm{P} 0$ & $\mathrm{P} 1$ & $\mathrm{P} 2$ & $\mathrm{P} 3$ \\
\hline 0 & $81,46 \pm 2,77^{\mathrm{a}}$ & $81,32 \pm 4,39^{\mathrm{a}}$ & $82,04 \pm 4,54^{\mathrm{a}}$ & $81,28 \pm 5,75^{\mathrm{a}}$ \\
6 & $76,44 \pm 3,77^{\mathrm{a}}$ & $74,34 \pm 3,63^{\mathrm{a}}$ & $77,82 \pm 2,85^{\mathrm{a}}$ & $77,52 \pm 3,36^{\mathrm{a}}$ \\
12 & $74,48 \pm 3,98^{\mathrm{a}}$ & $69,12 \pm 6,22^{\mathrm{a}}$ & $70,90 \pm 6,29^{\mathrm{a}}$ & $74,06 \pm 3,84^{\mathrm{a}}$ \\
18 & $71,38 \pm 3,62^{\mathrm{a}}$ & $67,06 \pm 5,97^{\mathrm{a}}$ & $65,50 \pm 6,31^{\mathrm{a}}$ & $69,14 \pm 4,55^{\mathrm{a}}$ \\
24 & $68,64 \pm 3,21^{\mathrm{a}}$ & $62,26 \pm 6,34^{\mathrm{a}}$ & $62,24 \pm 6,56^{\mathrm{a}}$ & $65,78 \pm 5,79^{\mathrm{a}}$ \\
30 & $65,00 \pm 4,79^{\mathrm{a}}$ & $59,48 \pm 5,91^{\mathrm{a}}$ & $58,14 \pm 8,93^{\mathrm{a}}$ & $63,22 \pm 6,37^{\mathrm{a}}$ \\
36 & $59,94 \pm 6,59^{\mathrm{a}}$ & $56,82 \pm 6,83^{\mathrm{a}}$ & $44,50 \pm 25,47^{\mathrm{a}}$ & $57,28 \pm 5,05^{\mathrm{a}}$ \\
42 & $58,34 \pm 6,28^{\mathrm{a}}$ & $54,20 \pm 7,79^{\mathrm{ab}}$ & $38,18 \pm 22,70^{\mathrm{b}}$ & $54,38 \pm 5,91^{\text {ab }}$ \\
48 & $51,98 \pm 8,03^{\mathrm{a}}$ & $43,58 \pm 24,75^{\mathrm{ab}}$ & $23,86 \pm 22,52^{\mathrm{b}}$ & $49,48 \pm 7,52^{\mathrm{a}}$ \\
\hline
\end{tabular}

Superskrip yang berbeda dalam baris yang sama menunjukkan perbedaan yang nyata $(\mathrm{P}<0,05)$.

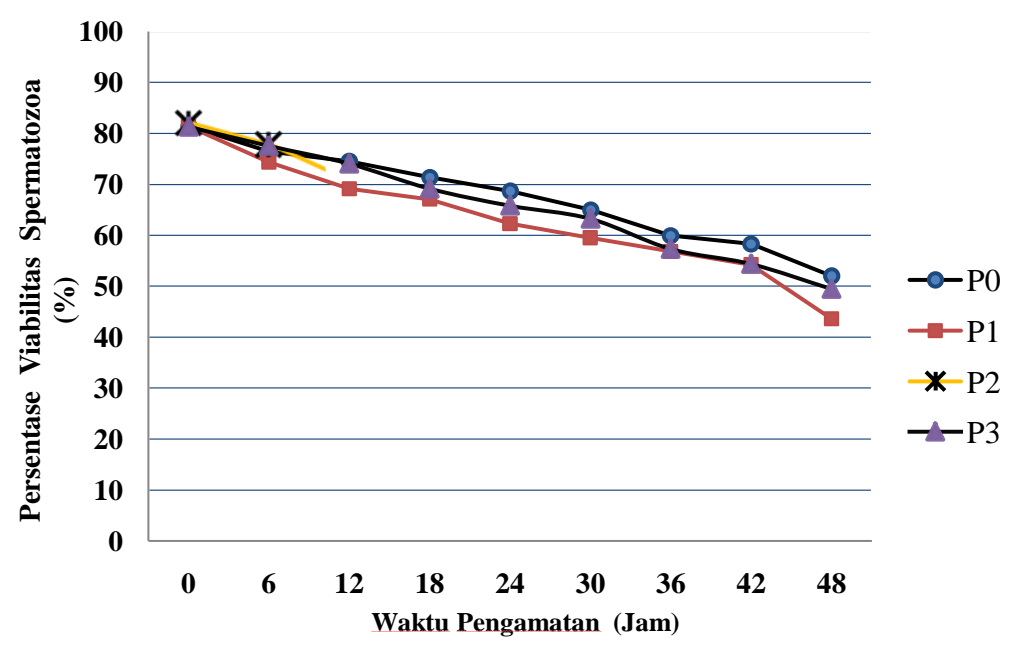

Gambar 2. Penurunan persentase viabilitas spermatozoa babi landrace

dengan lesitin kedelai sebanyak $6 \%(\mathrm{w} / \mathrm{v})$ yaitu $59,27 \pm 5,80 \%$ pada jam ke- 48 jam penyimpanan, namun lebih tinggi dari hasil penelitian Sumardani (2007) yaitu $36,33 \pm 1,89 \%$ pada pengamatan jam ke-42 yang menggunakan pengencer modifikasi Zorlesco dengan fruktosa pada suhu penyimpanan $18^{\circ} \mathrm{C}$. Semen babi memiliki keunikan dibandingkan dengan semen hewan mamalia lainnya. Semen cair pada ternak babi hanya dapat disimpan dan tetap dipertahankan kualitasnya pada kisaran suhu $15-20^{\circ} \mathrm{C}$ (Paulenz et al., 2000 dan Robert, 2006).
Pola penurunan viabilitas spermatozoa cukup tinggi 3,49-6,10\% terlihat pada awal pengamatan hingga jam ke-12 pada seluruh perlakuan, dimana penurunan viabilitas spermatozoa terendah pada perlakuan P0 yaitu sebesar 3,49\% dan penurunan tertinggi pada perlakuan P1 yaitu $6,10 \%$, penurunan ini terjadi karena spermatozoa dalam keadaan menyesuaikan dengan pengencer dan suhu penyimpanan (Sumardani, 2007).

Penurunan mulai stabil terlihat pada pengamatan jam ke-12 hingga jam ke-30 penyimpanan yaitu sebesar $2,86-4,92 \%$, dimana 
penurunan terendah teramati pada perlakuan $\mathrm{P} 0$ yaitu $2,86 \%$ dan tertinggi teramati pada P2 yaitu $4,92 \%$, fenomena ini juga terjadi karena spermatozoa telah menyesuaikan dengan bahan pengencer dan suhu penyimpanan untuk melakukan aktifitas metabolisme dengan baik, namun dengan bertambahnya umur spermatozoa selama penyimpanan maka ketersediaan sumber nutrisi mulai berkurang dan teramati pada jam ke-30 hingga jam ke-42 penurunan mulai cepat terjadi yaitu kisaran $5,43-12,79 \%$ terutama pada perlakuan $\mathrm{P} 2$ pola penurunan tertinggi (Gambar 2).

Penurunan viabilitas spermatozoa dipengaruhi juga oleh tingginya kandungan kalsium ekstraseluler dalam susu kedelai. Ada beberapa hal yang menyebabkan penurunan motilitas hingga kematian spermatozoa sehubungan dengan destabilisasi membran, diantaranya adalah; 1) meningkatnya konsentrasi kalsium bebas pada membran sel akan menyebabkan kematian spermatozoa, karena keberadaan kalsium bebas akan mengaktifkan enzim-enzim diantaranya adalah: (a). endonuclease, yang akan menghancurkan DNA dalam inti spermatozoa; (b). transglutaminase, yang berikatan secara kovalen dengan protein membran melalui pembentukan ikatan isopeptida yang mematikan sel; 2). Adanya perubahan susunan membran sel yaitu lipid (fosfolipid), kolesterol dan protein (Amann et al., 1993; Fuller dan Shields, 1998; Mann dan Mann, 2008).

Penurunan viabilitas spermatozoa juga dapat disebabkan oleh stres oksidatif yang dialami spermatozoa selama penyimpanan pada suhu dingin. Hal ini sesuai pendapat Susilawati (2011) bahwa proses pendinginan mengakibatkan stres fisik dan kimia pada membran sel yang dapat menurunkan viabilitas spermatozoa.

Rendahnya kualitas semen cair babi landrace dalam pengencer modifikasi Zorlesco dengan susu kacang kedelei 5\% selama penyimpanan ini mungkin disebabkan karena rendahnya kandungan sistein $0,01 \mathrm{~g} / 100 \mathrm{~mL}$ dalam pengencer Zorlesco yang tidak mampu mencegah terjadinya radikal bebas terutama dari larutan susu kacang kedelai terbentuknya peroksidasi lipid pada membran spermatozoa sehingga menghasilkan senyawa malondialdehyde (MDA) selama proses metabolisme sel (Lamarande et al., 1997 dan Liu et al., 2008). Proses metabolisme sel menghasilkan radikal bebas berupa derivat oksigen di antaranya adalah singlet oxygen, triplet oxygen, superoxide anion, hydroxyl radical dan nitric oxide. Singlet oxygen dapat merusak ikatan rangkap pada asam lemak sehingga dapat menyebabkan kerusakan pada DNA dan protein. Singlet oxygen jika bereaksi dengan salah satu asam amino sistein akan membentuk enzim yang dapat menyebabkan terdenaturasi protein (Sanocka dan Kurpisz, 2004; Sikka, 2004; Best 2006).

Semakin lama semen disimpan maka pHnya semakin menurun karena terjadi peningkatan asam laktat dalam jumlah yang besar. Pada $\mathrm{pH}$ rendah (asam) dapat menyebabkan penurunan metabolism rate (MR) spermatozoa. sedangkan pada $\mathrm{pH}$ netral $\mathrm{MR}$ akan meningkat (Ismaya et al., 2008).

Dibandingkan dengan jenis ternak lain, membran sel spermatozoa babi memiliki kandungan asam lemak tidak jenuh yang tinggi sehingga mudah rusak oleh ROS melalui proses peroksidasi lipid. Peroksidasi lipid akan menyebabkan peningkatan rigiditas dari membran sel, menurunkan kemampuan membran mengikat enzim (termasuk mengganggu pompa ion), mengganggu aktivitas reseptor pada membran serta mengganggu permeabilitas membran (Sanocka dan Kurpisz, 2004; Best, 2006; Liu et al., 2008).

Bahan pengencer yang mengandung lipoprotein dan lecithin berfungsi guna mempertahankan dan melindungi integritas selubung lipoprotein spermatozoa, sedangkan glukosa dapat dipergunakan oleh spermatozoa untuk metabolisme, Sedangkan stres oksidasi pada spermatozoa merupakan penyebab utama disfungsi spermatozoa dengan menghambat proses oksidasi fosforilasi. Oksidasi fosforilasi yang terganggu menyebabkan peningkatan ROS yang selanjutnya dapat menyebabkan oksidasi lipid, protein, dan DNA (Lamarande et al., 1997; Sanocka dan Kurpisz, 2004; Vyt et al., 2004).

Peroksidasi lipid paling banyak terjadi 
di membran sel, terutama asam lemak tidak jenuh yang merupakan komponen penting penyusun membran sel. Pengukuran tingkat peroksidasi lipid diukur dengan mengukur produk akhirnya, yaitu malondialdehyde (MDA), yang merupakan produk oksidasi asam lemak tidak jenuh dan yang bersifat toksik terhadap sel spermatozoa (Hammerstedt, 1993; White 1993; Maxwell dan Watson 1996).

Perubahan temperatur dan tekanan osmotik juga dapat mempengaruhi struktur komposisi lipid dari membran sel spermatozoa sehingga dapat menyebabkan penurunan motilitas spermatozoa (Gambar 10) (Amann dan Graham 1993 dalam Morel 1999; Ax et al., 2000b; Chun-Xia, 2000 dan Sumardani, 2007; dan Sumardani et al., 2008).

\section{SIMPULAN DAN SARAN}

\section{Simpulan}

Hasil penelitian ini disimpulkan bahwa modifikasi Zorlesco dengan penambahan susu kacang kedelai $5 \%$ dapat mempertahankan motilitas dan viabilitas spermatozoa hanya pada pengamatan jam ke-42 sebagai persyaratan program IB.

\section{Saran}

Berkaitan dengan inseminasi buatan, maka semen babi landrace cukup di encerkan dengan pengencer Zorlesco ${ }^{\circledR}$.

\section{DAFTAR PUSTAKA}

Aboagla, E.M.E. and T. Terada. 2004. Effect of supplementation of treahalose xtender containing egg yolk with sodium dodecyl sulfate on the freezability of goat spematozoa. Therioggenology 62: 12451250.

Amann, R.P., RH. Hammerstedt and D.N.R. Veeramachaneni. 1993. The epididymis and sperm maturation: a prespective. Reprod Fertil Dev 5:361-381.

Ardana, B. dan H. Putra. 2008. Manajemen Reproduksi, Produksi Dan Penyakit Ternak Babi. Udayana University Press. Bali.

Arifiantini, R.I. 2012. Teknik Koleksi Dan Evaluasi Semen Pada Hewan. IPB Press. Bogor.
Ax, R.L., M.Dally, B.A. Didion, R.W. Lenz, C.C. Love, D.D. Varner, B Hafez and M.E. Bellin. 2000a. Semen Evaluation. In: Hafez ESE, Hafez B, editor. Reproduction in farm Animals. $7^{\text {th }}$ Ed. USA: Williams \& Wilkins.

Ax, R.L., M.Dally, B.A. Didion, R.W. Lenz, C.C. Love, D.D. Varner, B Hafez and M.E. Bellin $2000_{\mathrm{b}}$. Artificial Insemination. In: Hafez ESE, B Hafez, editor. Reproduction in Farm Animals. ${ }^{\text {th }}$ Ed. USA: Williams \& Wilkins.

Bassol, J.E. Kadar. M.D Briz., E. Pinart., S. Sancho., N. Garcia-Gil., E.Badia., A Pruneda., M.G. Coll., E. Bussalleu., M. Yeste and S. Bonet. 2005. In vitro culture of boar epididymal epithelial cells. Theriogenology 63: 363-369.

Bearden. H.J., J.W. Fuquay., S.T. Willard. 2004. Applied Animal Reproduction. Ed ke-6. Pearson Education Inc. New Jersey.

Beaulieu, M., C. Dube., C. Reyes-Moreno., C. Guillemette and J.L.Bailey. 2005. Differential effects of BTS and Androhep on boar semen. Di dalam : Gadella B.M \& B Colenbrander, editor. Proceedings of the V International Conference on Boar Semen Preservation; Doorwerth, The Netherlands, 24-27 August 2003. Theriogenology 63: 422-430.

Bergeron, A. and P. Manjunath. 2006. New insights towards under-standing the mechanisms of sperm protection by egg yolk and milk. Mol. Reprod. Dev. 73: 13381344

Best, B. 2006. Viability, cryoprotectant toxicity and chilling injury in cryogenics. www.benbest.com/resources/cryopreservati on.pdf. [30 Juli 2006].

Blakely, J. dan D.H. Bade. 1992. Ilmu Peternakan. Edisi.4. Srigandono B, penerjemah: Gadjah Mada University Press. Yogyakarta. Indonesia.

Bonet, S., M. Briz. and A. Fradera. 1993. Ultrastructural abnormalities of boar spermatozoa. Theriogenelogy 63 : 383-396.

Campbell, N.A., J.B. Reece and L.G. Mitchell. 2002. Biologi. Ed Ke-5. Jilid I. Erlangga. Jakarta.

Chun-Xia, Z., Y. Zeng-Ming. 2000. Evaluation on sperm quality of freshly ejaculated boar semen during in vitro storage under different temperatures. Theriogenology 53(7): 1477-1488.

Colenbrander, B., A.R Fazeli, A. Van Buiten, J. Parlevliet and B.M. Gadella. 1992. 
Assesment of sperm cell membran integrity in the horse. Act Vet Scand. Supl. $88: 49$ 58.

Crabo Bo, G. 2001. Physiological aspects of stallion semen cryopreservation. AAEP Proceeding Vol $47: 291$ - 294.

Everett, R.W. and B. Bean. 1982. Environmental influence on semen output. J. Dairy Sci. 65:1303-1310.

Feradis. 2010. Bioteknologi Reproduksi Pada Ternak. Bandung. Alfabeta.

Fuller, G.M. and D. Shields. 1998. Molecular Basis of Medical Cell Biology. Prentice Hall International, Inc. USA.

Gadea, J. 2003. Semen extenders used in the artificial insemination of swine. Spanish Journal of Agricultural Research 1 (2): $17-$ 27.

Garner, D.L. and E.S.S. Hafez. 2000. Spermatozoa and Seminal Plasma. In: Hafez ESE, and B. Hafez, editor. Reproduction in farm Animals.7th Ed. USA: Williams dan Wilkins.

Gilt, J., M.R. Irazoqui, N. Lundeheim, L. Soderquist and H.R. Martinez. 2003. Fertility of ram semen frozen in Bioxcell ${ }^{\circledR}$ and Triladyla ${ }^{\circledR}$ extender for cryopreservation of bull semen. Animal Reproduction. Science 42:55-65.

Hafez, B. and E.S.E Hafez. 2000. Reproductive Behavior. In: Hafez ESE, Hafez B, editor. Reproduction in farm Animals.7th Ed. USA: Williams \& Wilkins. Philadelpia.

Hammerstedt, R.H. 1993. Maintenance of bioenergetic balance in sperm and prevention of lipid peroxidation : a Review of The effect on design of storage preservation systems. Reprod Fertil Dev 5 : 675-690.

Ismaya. Kustono, S. Bintara dan D.T. Widayati. 2008. Teknologi Reproduksi Ternak. Fakultas Peternakan. Universitas Gadjah Mada. Yogyakarta.

Johnson, L.A., K.F. Weitze, P. Fiser and W.M.C. Maxwell. 2000. Storage of boar semen. J Anim Sci 62: 143-172.

Lamarande, E., H. Jiang, A. Zini, H. Kodama and C. Gagnon. 1997. Reactive oxygen species and sperm physiology. Review of Reproduction 2: 48-54.

Liu, C., X. Wang, H. Ma, Z. Zhang, W. Gao and L. Xiao. 2008. Functional properties of protein isolates from soybeans stored under various conditions. J Food Chem 111:29-37.
Mann, K. and M. Mann. 2008. The chicken egg yolk plasma and granule proteomes. Proteomics 8:178-191.

Maldjian, A., F. Pizzi, T. Gliozzi, S. Cerolini, P. Penny and R. Noble. 2005. Changes in sperm quality and lipid composition during cryopreservation of boar semen. Theriogenology $63: 411-421$

Maxwell, W.M.C and P.F. Watson. 1996. Recent progress in the preservation of ram semen. Animal Reproduction Science 43: 55-65.

Neil, D.M. 2005. Evaluation of equine sperm membrane fuction effect of cryopreservation. Thesis Utrecht : Utrecht University. Netherlands.

Paulenz, H., E. Kommisrud and P.O. Hofmo. 2000. Effect of long-term storage at different temperatures on quality of libido boar semen. Reprod Dom Anim 35 : 83-88.

Robert, V.K. 2006. Semen processing. Extending \& Storage for Artificial Insemination in Swine. Dept. of Animal Science University of Illinois.

Sanocka, D. and M. Kurpisz. 2004. Reactive oxygen species and sperm cells. Reproductive Biology and Endocrinology 2 (12): $1-7$.

Shipley C.F. 1999. Breeding sounders examination of the boar. Swine Health Prod. 7 (3) : 117120.

Shukla, S.N., B.B Sigh, N.S. Tomar, and B.S Misra. 1992. Factor effecting spermatozoa motility in preserved semen. J. Indian Vet.69:856857.

Sikka, S.C. 2004. Role of oxidative stress and antioxidants. in andrology and assisted. reproductive technology. Journal Androl. 25:5-18.

Situmorang, P. 2002. The effect of inclusion of exogenous phospholipid in tris diluents containing a different level of egg yolk on the viability of bull spermatozoa. JITV 7 (3):181-187.

Sumardani, N.L.G. 2007. Viabilitas dan fertilitas spermatozoa dalam modifikasi bts dan zorlesco dengan penyimpanan berbeda dalam rangkaian inseminasi buatan pada babi. Tesis. Program Studi Biologi Reproduksi. Institut Pertanian Bogor. Bogor.

Sumardani, N.L.G., L. Y. Tuty dan H.S. Pollung. 2008. Viabilitas spermatozoa babi dalam pengencer beltsville thawing solution (BTS) pada tiga tempat penyimpanan berbeda. Seminar Nasional Teknologi 
Peternakan dan Veteriner 2008. Media Peternakan $31: 81-86$

Susilawati, T. 2011. Spermatology. UB Press. Universitas Brawijaya. Malang.

Toelihere, M.R. 1993. Inseminasi Buatan pada Ternak. Bandung: Angkasa.

Van Wagtendonk, F.E., A.M. De Leeuw, R.M. Haring, L.M.T.E. Kaal Lansbergen and J.H.G. Den Daas. 2000. Fertility results using bovine semen cryopreserved with extenders based on egg-Yolk and soy Bean exract. Theriogenology, 54:57-67.

Vyt, P., D. Maes, D. E. Dejonckheere, F. Castryck and A. Van Soom. 2004. Comparative study on five different commercial extenders for boar semen. Reprod Domest Anim 39: 8-12.

Waberski, D., K.F Weitze, D. Rath and H.P. Salman. 1989. Effect of bovine serum albumin and zwitterionic buffers on stored liquid boar semen. Zuchthygiene 24: 128133.

White, I.G. 1993. Lipid and calcium uptake of sperm in relation to cold shock and preservation : A review. Reprod Fertil Dev 5: 639-658.

Zhang, S., J.H. Hu, L. Qing-Wang, J. Zhong-Liang and Z. Xiao-Ying. 2009. The cryoprotective effects of soybean lecithin on boar spermatozoa quality. African Journal of Biotechnology 8 (22), pp. 6476-6480. 